\title{
Dyskurs antysemicki w krytyce artystycznej Stanisława Pieńkowskiego na łamach „Myśli Narodowej" (1924-1937)
}

Diana Wasilewska

TEKSTY DRUGIE 2020, NR 4, S. 317-331

DOI: 10.18318/td.2020.4.17 | ORCID: 0000-0002-9146-6599

Słowa mogą być jak malutkie dawki jadu, połyka się je niepostrzeżenie, wydają się nie mieć żadnego skutku, a jednak po pewnym okresie następuje trujące działanie.

Victor Klemperer ${ }^{1}$

$\mathbf{P}$ oczątki antysemickiej, nienawistnej mowy w nowoczesnej publicystyce polskiej wyznacza powstanie w roku 1883 tygodnika „Rola”. Jego redaktor, pozytywista Jan Jeleński, zdążył już wcześniej wsławić się kilkoma antyżydowskimi broszurami². Przestrzegał w nich przed zagrożeniem ze strony Żydów, ratunek widział jednak, jak większość ówczesnych publicystów, w asymilacji wrogiego narodu i choćby częściowym ograniczeniu jego

1 V. Klemperer LTI. Notatnik filologa, oprac. J. Zychowicz, Wydawnictwo Literackie, Kraków 1983, s. 23-24.

2 Zob. A. Cała Żyd-wróg nasz odwieczny? Antysemityzm w Polsce i jego źródła, Nisza, Warszawa 2012, s. 265.

\section{Diana Wasilewska}

- dr, historyk

i krytyk sztuki (UAM), polonistka (UMK),

absolwentka pody-

plomowego studium

Laboratorium Repor-

tażu (UW). Autorka

dwóch monografii

naukowych po-

święconych krytyce

artystycznej między-

wojnia; stypendystka

Fundacji Lancko-

rońskich (2009);

kierownik grantu

NCN. W badaniach

naukowych zajmuje

się przede wszystkim

krytyką artystyczną

dwudziestolecia

międzywojennego,

ze szczególnym

uwzględnieniem

retorycznego

aspektu jej języka.

Pracuje na Wydziale

Sztuki Uniwersytetu

Pedagogicznego

w Krakowie. 
praw. Poglądy Jeleńskiego z okresu redagowania pisma znacząco się jednak zradykalizowały - równolegle do zmian w obszarze języka wypowiedzi i stosowanych narzędzi retorycznych. „Rola”, jak dowiodła Alina Cała, była na terenie polskim prekursorką nowoczesnych technik agitacyjnych rodem z niemieckich pism propagandowych ${ }^{3}$. Przodowała też w stosowaniu inwektyw, personalnych ataków i niewybrednych, napastliwych oszczerstw. Wkrótce w jej ślady poszły inne pisma pozytywistyczne, jak konserwatywna „Niwa”, a negatywnie o tzw. sprawie żydowskiej, choć w łagodniejszym tonie, wypowiadali się m.in.: Aleksander Świętochowski, Henryk Sienkiewicz, Bolesław Prus czy Eliza Orzeszkowa ${ }^{4}$. Jednak dopiero powstanie ugrupowań skrajnie nacjonalistycznych oraz ich prasowych organów, jak „Głos” czy „Przegląd Wszechpolski”, na dobre rozpętało antyżydowską, nasilającą się z każdym rokiem nagonkę. Budowanie klimatu „oblężonej twierdzy” oraz utrwalanie stereotypu spiskującego Żyda, obcego narodowi polskiemu zarówno pod względem kultury, temperamentu, jak i duchowości, było charakterystyczne dla wypowiedzi przede wszystkim Teodora Jeske-Choińskiego, Konstantego Wzdulskiego, Jana Ludwika Popławskiego i Romana Dmowskiego. Za źródło inspiracji służyła tu głównie publicystyka niemiecka i francuska, ale odkrywano też na nowo rozprawy Stanisława Staszica i nieprzychylną Żydom literaturę staropolską̧.

Po I wojnie światowej antysemicki dyskurs ożył ze zdwojoną siłą, nabierając dodatkowych rumieńców w związku z wojną bolszewicką ${ }^{6}$. Ludowy, negatywny stereotyp Żyda jako przebiegłego szachraja został wzbogacony nowymi elementami. Przedstawiciele narodu semickiego, oskarżani teraz o (współ)tworzenie rewolucji sowieckiej, byli ukazywani jako wyjątkowo groźni, okrutni, skłonni do zabijania i niszczenia kultury chrześcijańskiej’. Odtąd nie tylko szyderstwa, obelżywe epitety i wyzwiska, ale też posądzanie Żydów o wszelkie możliwe zbrodnie były na porządku dziennym - szczególnie w prasie o profilu skrajnie prawicowym (pisma endeckie, Młodzieży

3 Tamże, s. 267 in.

4 Tamże, s. 287-288.

5 Tamże s. 291.

6 Termin „żydokomuna” będzie w krytyce antysemickiej dość pojemny i posłuży do określania tym mianem właściwie całej, także artystyczno-literackiej, lewicy.

7 Zob. I. Kamińska-Szmaj Judzi, zohydza, ze czci odziera. Język propagandy politycznej w prasie 1919-1923, Towarzystwo Przyjaciół Polonistyki Wrocławskiej, Wrocław 1994, s. 127. 
Wszechpolskiej, ale też katolickie, jak „Pro Christo” czy gazety nadzorowane przez ojca Maksymiliana Marię Kolbego $\left.{ }^{8}\right)$. Kulminacja nastrojów antyżydowskich przypadła na lata 30., naznaczone wielkim kryzysem ekonomicznym, nasileniem się tendencji nacjonalistycznych, a w obszarze artystycznym osłabieniem etosu awangardy, zwrotem w stronę natury, człowieka i znamion stylu narodowego ${ }^{9}$. Tubą antysemitów były przede wszystkim takie pisma jak: „ABC”, ,Prosto z Mostu”, ,Myśl Narodowa”, „Gazeta Warszawska”, „Kurier Poznański” czy katolicka „Kultura”. Stosunek do rasy semickiej stał się nierzadko wyznacznikiem przynależności do określonej orientacji politycznej oraz jednym z bardziej skutecznych narzędzi walki po obu stronach barykady. Zarówno przez prasę codzienną, jak i opiniotwórcze periodyki o profilu społeczno-politycznym przetoczyła się szeroka debata poświęcona tzw. kwestii żydowskiej. Złowroga figura Żyda „straszyła” jednak nie tylko w syntezach, analizach sytuacji politycznej i gospodarczej, ale też w licznych wypowiedziach literatów, artystów i krytyków tamtego okresu.

Jednym z najbardziej „zasłużonych” publicystów w walce z „żydostwem” w kulturze polskiej okazał się Stanisław Pieńkowski - poeta-samouk, krytyk teatru, literatury i sztuk wizualnych, redaktor "Gazety Warszawskiej” oraz „Myśli Narodowej”, w tym ostatnim piśmie prowadzący w latach 1929-1930 stałą rubrykę poświęconą sztukom plastycznym ${ }^{10}$.Z kilkudziesięciu artykułów powstałych w ciągu tych niespełna dwóch lat tylko nieliczne pozbawione były antysemickich ataków czy choćby aluzji wobec narodu żydowskiego ${ }^{11}$. Ich

8 Chodzi m.in. o "Rycerza Niepokalanej” i "Mały Dziennik" - pisma miały w roku 1930 nakład 800 tys. egzemplarzy.

9 Jak pisze R. Golan, we Francji tendencje antysemickie szły w parze z owym antyawangardowym klimatem epoki oraz rosnącym kryzysem, wiązanym z odejściem od natury, wsi i zainteresowania człowiekiem na rzecz czysto matematycznych łamigłówek abstrakcjonistów. Żydzi łączeni byli bowiem nie tylko z bolszewizmem, ale też z przywiązaniem do miasta i maszyny, a więc w opozycji do tęskniącego za powrotem do natury człowieka. Zob. R. Golan Modernity and Nostalgia. Art and Politics in France between the Wars, Yale University Press, New-HavenLondon 1995.

10 Pieńkowski redagował kolumnę plastyki od kwietnia 1929 do końca 1930 roku. Potem okazjonalnie pisywał w "Myśli Narodowej” o sztuce, literaturze i teatrze. Poza tym publikował we wspomnianej "Gazecie Warszawskiej", naczelnym organie endecji, a także w "Gazecie Porannej”, w „Rzeczpospolitej" czy w "Słowie Polskim”.

11 Pieńkowski, jak wielu nacjonalistów, zaczął swą karierę jako aktywny działacz ruchu socjalistycznego, rywalizując o popularność choćby ze Stanisławem Brzozowskim. Jednak jeszcze przed I wojną światową diametralnie zmienił swe poglądy, zgłaszając akces do środowiska związanego z obozem narodowym. Odtąd angażował się nie tylko jako krytyk literacki, teatral- 
autor posługiwał się ostrym, nierzadko „rynsztokowym” stylem, znajdującym, w jego mniemaniu, usprawiedliwienie w randze sprawy, o jaką walczył. Miał bowiem Pieńkowski poczucie misji. Uważał siebie za jedynego sprawiedliwego krytyka, który nie tylko widział i wiedział więcej niż inni, ale też nie bał się obwieszczać tego światu. I czynił to konsekwentnie, z niesłabnącą, obsesyjną wręcz gorliwością, tępiąc wszelkie, choćby tylko domniemane lub nawet wyimaginowane, przejawy żydowskości w polskiej kulturze. Nie traktowano go jednak jako nieszkodliwego wariata, a jego tekstów - jako wytworów chorego umysłu ${ }^{12}$. Kilkukrotnie pozywany i policzkowany, był prawdziwym postrachem ówczesnego światka artystyczno-literackiego ${ }^{13}$. A zapalczywością i inwencją w wynajdowaniu obraźliwych inwektyw dorównywał mu chyba tylko rzeźbiarz Stach z Warty Szukalski i jego świta skupiona wokół pisma „Krak"14.

Owa gorliwość Pieńkowskiego-tropiciela wynikała z żywionego przezeń przekonania o wszechwładnej obecności Żydów we wszystkich sferach życia, w tym artystycznych. Z uporem godnym lepszej sprawy badał on stopień i mechanizmy „zażydzania” Polski i związane z tym zagrożenia. Odsłaniał tym samym typowy dla antysemickiego dyskursu „lęk przed

ny i artystyczny, ale także jako publicysta polityczny. Zob. P. Stachowiak Inspiracje rasistowskie w polskich środowiskach nacjonalistycznych okresu międzywojennego. O publicystyce politycznej Stanisława Pieńkowskiego, w: Nacjonalizm polski do 1939 roku. Wizje kultury polskiej i europejskiej, Wydawnictwo UMCS, Lublin 2011, s. 375.

Artykuły Pieńkowskiego drukowane były w ważnych wysokonakładowych pismach endeckich i szanowanych wydawnictwach, należało więc brać je na poważnie.

Do jednego z owych głośnych procesów o zniesławienie doszło w 1928 roku. Pieńkowski został oskarżony o obrazę dobrego imienia polskiego artysty - był nim Mieszko Jabłoński, krakowski malarz, którego krytyk na łamach endeckiej "Gazety Porannej" nie tylko nazwał żydowskim (uznając po prostu, że ów "po żydowsku” maluje), ale też przeprowadził pełną nienawistnego jadu krytykę jego prac. Jak informowały pilnie śledzące sprawę i oburzone działaniem Pieńkowskiego "Sztuki Piękne", rzecz zakończyła się wyrokiem skazującym publicystę na dwa lata więzienia (zob. Kronika artystyczna, "Sztuki Piękne” 1929 nr 1). Być może był to jednak wyrok w zawieszeniu, zważywszy na to, że pod koniec 1929 roku Pieńkowski zaczął współpracę z "Myślą Narodową", dając już niczym niezmącony upust swej nienawiści do narodu żydowskiego.

Z napastliwych wypowiedzi antysemickich słynęli też: propagator faszyzmu i nazistowskich czystek Adolf Nowaczyński, krytyk i jeden z głównych ideologów Narodowej Demokracji Zygmunt Wasilewski, młody satyryk Karol Zbyszewski oraz, choć bardziej incydentalnie, Konstanty Ildefons Gałczyński czy Karol Irzykowski. Zob. M. Domagalska Antysemityzm dla inteligencji? Kwestia żydowska w publicystyce Adolfa Nowaczyńskiego na łamach „Myśli Narodowej (1921-1934) i „Prosto z Mostu (1935-1939) (na tle porównawczym), Żydowski Instytut Historyczny, Warszawa 2004. 
zalaniem", a więc omniprezencją Żydów, idący zresztą w parze z fantazmatem ich wszechmocy („lęk przed zatruciem”) ${ }^{15}$. Żydzi, dowodził, nie tylko zawładnęli rynkiem sztuki, ale też „rozplenili się” w roli krytyków i artystów - i to do tego stopnia, że "dzisiaj kroku stąpnąć nie można, żeby w żyda nie wdepnąć" ${ }^{\prime 16}$. Nawał Żydów zalewał jego zdaniem nie tylko ulice miast, ale też stowarzyszenia i instytucje, „zapchane panoszącymi się przybyszami obcej rasy" były również wystawy i czasopisma. Pieńkowski nie widział miejsca dla Żydów w obszarze narodowej kultury - skoro ich sztuka „tak obrodziła, [...] powinni stworzyć własne bractwo św. Eliasza, własną Zachętę i własny rynek zbytu i nie plątać się pod cudzymi znakami"17. Krytyk nie miał tu jednak na myśli wyłącznie twórców otwarcie przyznających się do swoich korzeni. Przedmiotem jego ataku byli również, a nawet przede wszystkim artyści zasymilowani, podpisujący się „kupowanymi” polskimi nazwiskami, a więc tylko „udający Polaków”"18. Niemal całą powojenną sztukę i literaturę Pieńkowski określił mianem „kryptożydowskiej", nie zawsze posiłkując się wiedzą o faktycznym pochodzeniu atakowanych twórców. Właściwie każdy, kto prezentował odmienny pogląd na sztukę $^{19}$ lub schlebiał głosicielom takich stanowisk, zasługiwał tu na miano „kryptożyda”. Owo pojęcie było więc dość pojemnym workiem, pełniąc zarówno funkcję wygodnego wytrychu, jak i narzędzia druzgocącej ceny. Uzasadnieniem swych sądów krytyk nie zawsze się przejmował - w końcu, jak pisał, „w maskaradzie obecnych czasów wszystko jest możliwe”20.

15 Wykładnię tych pojęć w kontekście dyskursu antysemickiego przejmuję za: K. Ambroziak Co wyraża dyskurs antysemicki, w: Analizować nienawiść. Dyskurs antysemicki jako tekstowe wyzwanie, red. P. Kuciński, G. Krzywiec, Wydawnictwo IBL PAN, Warszawa 2011, s. 39-40.

16 S. Pieńkowski Metabolicznie, "Myśl Narodowa” 1930 nr 7, s. 11.

S. Pieńkowski Bractwo św. Łukasza „ „Myśl Narodowa” 1929 nr 49, s. 302.

18 Pieńkowski negował każdą możliwość asymilacji Żydów, uznając ją przy tym za niepożądaną, a wręcz szkodliwą. ,Żydzi - pisał jeszcze przed wojną - są żydami bez względu na język, kulturę i wyznanie". Zob. S. Pieńkowski Dwa żywioły. Głos w sprawie żydowskiej, F. Wyszyński i S-ka, Warszawa 1913, s. 46.

Naturalnie nie tylko na sztukę, podobny los spotkał zwolenników liberalizmu, socjalizmu czy masonów - a więc właściwie wszystkich, którzy nie identyfikowali się z ideologią nacjonalistyczną.

20 Funkcjonowanie w świecie prawd wyobrażonych, które nie potrzebują potwierdzenia w faktach, było zjawiskiem typowym dla dyskursu antysemickiego. 
Opętany spiskowym widzeniem świata Pieńkowski dowodził, że jedną z podstawowych właściwości wrodzonej, niezmiennej historycznie i niemodyfikowalnej natury żydowskiej jest skłonność do oszustw, maskowania się i ukrywania. „Żydzi fałszują wszystko - od masła do religii”21 - kwitował w jednym z artykułów. Powielając stereotyp spiskującego Żyda, znany z ludowych wierzeń i Protokołów mędrców Syjonu, Pieńkowski wzmacniał go jeszcze rzekomo naukowymi dowodzeniami o patologicznym przeroście mózgu u rasy semickiej oraz jej całkowitej niezdolności do działania intuicyjnego, właściwego wszelkim innym narodom ${ }^{22}$. Dodawał przy tym, że skłonność do abstrakcyjnego myślenia, spekulacji, kalkulowania i odrzucania wrażeń czy emocji na rzecz czysto "mózgowych" dociekań znalazła odbicie również w polu artystycznym, wpływając na preferencje artystów i właściwości ich dzieł. Kierując się takim przekonaniem, potępiał malarstwo abstrakcyjne i rzeźbę konstruktywistyczną, a właściwie wykluczał z obszaru rdzennej sztuki polskiej całą, nie tylko skrajną awangardę. Podobny los spotkał bowiem formistów i rytmistów, którzy nie tworzyli przecież ani sztuki abstrakcyjnej, ani też czysto spekulatywnej. Dla zwolennika ekspresyjnego realizmu i symbolizmu, za jakiego uważał się Pieńkowski (not bene gorliwy wielbiciel Wyspiańskiego i Malczewskiego), absolutyzowanie formy, uproszczenie i geometryzacja kształtów oraz silne oparcie w teorii artystycznej były nie do przyjęcia. A ponieważ wśród członków ugrupowań powstałych po wojnie figurowali też Żydzi, krytyk znalazł sposób na to, by wszelkich nowatorów hurtowo potępić. Ukuł mianowicie termin , judoformizm”, mianując tą nazwą polskich twórców uważających się za „lewicowców” oraz współpracujących z nimi Żydów (w tym tych, którzy - jak twierdził - tylko udają Polaków): „Rasowe to i niedouczone chamstwo żydowskie - pisał - trafiło dziś na chwilowe i przejściowe chamstwo nowych warstw polskich, co razem dało potworka zwanego judoformizmem” $i$ „ukrywającego się pod maskami stu różnych izmów od dziesięciu lat grasujących w Polsce"23. Wspomniana przez krytyka lewicowość nie musiała naturalnie wynikać z faktycznych poglądów twórców. Był to tylko kolejny chwyt retoryczny, który pozwalał awangardę - kojarzoną wszak z rewolucyjnością i wywrotowością - połączyć ze

S. Pieńkowski Od ławy szkolnej, „Myśl Narodowa” 1937 nr 3, s. 35.

S. Pieńkowski Geniusz oszustwa , Myśl Narodowa” 1932 nr 41, s. 592.

23 S. Pieńkowski Uwaga wstępna, "Myśl Narodowa” 1929 nr 44, s. 238; S. Pieńkowski Radość życia,
„Myśl Narodowa” 1930 nr 14, S. 253. 
znienawidzonym przezeń bolszewizmem, a tym samym znaleźć uzasadnienie dla jakże powszechnej w antysemickim dyskursie kontaminacyjnej formuły żydokomuny ${ }^{24}$.

"Judoformizm" - jako sztuka pozbawiona artyzmu, bo schlebiająca "talmudycznej geometrii", a nadto skoligacona z bolszewizmem - zasługiwał więc nie tylko na potępienie, ale na całkowitą eliminację z obszaru kultury, stając się co najwyżej materiałem do „analizy psychopatologii”. Analizy, której Pieńkowski poświęcił zresztą niejedną szpaltę swej niechlubnej rubryki, skupiając się głównie na tym, by dać upust własnej, opętanej antyżydowską obsesją, wyobraźni. W niewielkim stopniu interesowały go konkretne obiekty oglądane przezeń na licznych warszawskich wystawach. W najlepszym razie napomykał coś o „kształcie bez wyrazu", "chlapaniu tępymi farbami”, „niedołęstwie stylu” czy "modulacji bez celu i myśli". Na ogół jednak interpretację zastępowała tu demaskacja, a jego osobliwe recenzje były ciągiem inwektyw i arbitralnych, nieuzasadnionych niczym ocen bądź też przybierały kształt szyderczo-ironicznych kalamburów. Cel był w obu przypadkach jeden: wykazać karygodnie niski poziom artystyczny tych prac i powiązać go z cechami o typowo żydowskiej proweniencji ${ }^{25}$. Wykorzystując potoczny żargon i poufały ton, pogardliwe deminutywy, złośliwy, a momentami szyderczy śmiech oraz właściwe dla swego stylu rymowanie, pisał krytyk o wystawie „Rytmu” w Salonie (Polaka!) Garlińskiego:

24 Opisując nierozerwalny związek bolszewizmu zżydostwem, Pieńkowski sięgał po sprawdzoną zwierzęcą metaforykę, okraszoną sporą dozą szyderstwa mającego wzbudzić wstręt do opisywanego przedmiotu: „Komunizm, zrodzony trzy tysiące lat temu z matki złości i z ojca fanatyzmu, odradza się i wypełza na świat, ilekroć żydzi dochodzą do wpływów i władzy. Stroi się wtedy na modę danego czasu, bielidłami i różami się odświeża i udaje ideę młodą, najmłodszą, postępową, świat zbawić mającą, ale jego stare kły próchnieją cuchnące, jadem się ślinią, który zgorzelą trupią zaraża i zabija. Jako z ducha żydowskiego poczęty, w każdym poruszeniu swoim jest kłamstwem, w każdym skręcie - oszustwem, w każdym słowie - fałszem. Żydzi w pochodzie swym koczowniczym puszczają przed sobą tego płaza, aby im drogę torował i miejsce dla nich sposobił [...]. W obrębie getta chadza ten krokodyl swobodnie po śmietnikach i mykwach, jako zwierz oswojony, nikomu ze swoich szkody nie czyniąc, albowiem jest on we własnej osobie objawieniem żydowskiego ducha narodowego. Bachorki na jego grzbiecie jeżdżą i wszy mu z łusek wydłubują". S. Pieńkowski Socjalizacja sztuki , "Myśl Narodowa" 1930 nr 5, s. 77.

Pieńkowski wypowiadał się negatywnie też o takich polskich artystach jak Władysław Skoczylas, Zofia Stryjeńska czy Tadeusz Pruszkowski, tylko dlatego, że byli związani z instytucjami rządowymi, jak Instytut Propagandy Sztuki czy TOSSPO, tudzież byli promowani przez (pro)żydowskich krytyków. 
W rubryce zupełnego i rozbrajającego w swej nieświadomości nieuctwa zamieścić należy przede wszystkim obrazy trzech żydów - p. Gottlieba, Husarskiego i Kramsztyka. W szczególności dwaj pierwsi czynią wrażenie chłopczyków bawiących się pędzlami i farbami: p. Gottlieb jako niegrzeczny Dyzio (z powieści Żeromskiego), a pan Husarski jako ten z bajki Tadeuszek, co nałapał w szklaneczkę muszek. Co do p. Kramsztyka, to malarstwo jego ani na krok z pierwotnych swych brudów nie wyszło, owszem - zapada się w nie tak beznadziejnie, że artysta poczuł konieczność malowania murzynów. Ale i ta ucieczka do lasów afrykańskich mało p. Kramsztykowi pomogła. Chyba zastosuje nadto motyw nocy czarnej i kawy czarnej, ażeby źródła natchnień swych otoczyć tajemnicą mojżeszowych objawien..$^{26}$

Ów drwiący „chichot” Pieńkowskiego miał być zabiegiem nie tylko stylistycznym, ale przede wszystkim perswazyjnym: demaskował rzekomo niski poziom artystyczny malarzy, sprowadzając ich do chlapiących farbą dzieci, ale też odwracał uwagę odbiorcy od samych dzieł, przenosząc ją na ośmieszone sylwetki ich autorów.

Pisząc o jawnie- i kryptożydowskich artystach czy krytykach, publicysta „Myśli Narodowej” dawał brawurowy popis swej pomysłowości w konstruowaniu inwektyw, napastliwych określeń i porównan - mocno okraszanych oceniającymi epitetami. Oprócz stosowania obraźliwych derywatów pochodzących od słowa „Żyd”, zawsze pisanych minuskułą („żydki”, „żydziaki”, „żydóweczki”, „żydłaczysko”) wykazywał on wyraźną predylekcję do metaforyki zwierzęcej - i to szczególnego rodzaju. Najczęściej sięgał po nazewnictwo konotujące zarazę, plagę czy śmiercionośną chorobę. Porównywał Żydów do pcheł i pasożytów, nazywał ich krwiopijcami, „pejsatymi pluskwami”, robactwem, pierwotniakami, „oślizgłymi gadami” czy „semicką bakterią". Owa terminologia, znana choćby z antysemickiej publicystyki niemieckiej, z Mein Kampf Hitlera, ale też z „żydożerczej” krytyki końca XIX wieku ${ }^{27}$, pojawiała się z taką obsesyjną frekwencją w tekstach Pieńkowskiego nie bez powodu, wiązała się bowiem ściśle z jego nacjonalistycznymi poglądami. Za Romanem Dmowskim zwolennicy endecji definiowali

S. Pieńkowski Sztuki plastyczne. Wystawa grupy „Rytm”, "Myśl Narodowa” 1929 nr 52, s. 350.

27 Po podobne dehumanizujące Żydów określenia, wzorem antysemickiej publicystyki niemieckiej, sięgali u nas choćby redaktorzy "Kultury Polskiej” wydawanej w latach 1908-1912 przez Aleksandra Świętochowskiego. Zob. A. Cała Żyd-wróg odwieczny, s. 292. 
naród w kategoriach biologicznych - jako spójny, jednolity organizm, którego zdrowe funkcjonowanie, twórczy potencjał i siły witalne zależą od umiejętności radzenia sobie z osłabiającymi go wirusowymi infekcjami i bakteriami ${ }^{28}$. Jeśli zaś zarażone „tkanki” nie podejmują stosownej walki, ulegają stopniowemu rozkładowi, doprowadzając z czasem do obumarcia całego organizmu. Stosowanie terminologii zwierzęcej, zwłaszcza określeń związanych z wszelakiej maści robactwem, miało więc służyć podkreśleniu zagrożeń, jakie dla polskiego narodu-organizmu niesie „bakteria człowiecza - żydem zwana"29. Porównywanie semickich artystów do insektów miało też na celu wskazanie, że mowa tu nie o pojedynczych przypadkach, ale o ogromnych skupiskach, o trudnej do wytępienia i szybko rozrastającej się zarazie. Inną grupę słów z wokabularza zwierzęcego, równie chętnie wykorzystywaną przez krytyka, stanowiły leksemy konotujące agresywne i bezlitosne zachowania wrogiego narodu. Pieńkowski nazywał Żydów szarańczą, stadem hien, kłębowiskiem szakali. Stopień grożącego Polsce niebezpieczeństwa oddawać miały także odzwierzęce czasowniki określające sposób działania Żydów i skalę spustoszenia, jakie ono ze sobą niosło. $\mathrm{Z}$ artykułów Pieńkowskiego dowiadujemy się zatem, że Żydzi grasują, żerują, ryją i kwiczą, pierzą się, roją się, gromadzą, oblepiają, obsiadają, rozpleniają się, żrą się, ale też „wysysają polską krew” i „wysyłają trujące gazy”. Do znamion „żydowskiego ducha”, nieobcych też judoformistom, a nade wszystko skamandrytom, krytyk zaliczył również nekroforyzm, koprofagię, porkografię oraz plazmatyzm, czemu z kolei odpowiadać miały takie zachowania jak: „przesiadywanie na trupach”, ,babranie się w zgniliźnie, kale i ścierwie" czy siedzenie w bagnie ${ }^{30}$. Takie dehumanizujące Żydów określenia, nierzadko występujące w sporym zagęszczeniu w danym tekście, spełniały przede wszystkim funkcję impresywną - miały wzmagać siłę sugestii, tj. wywoływać w czytelniku z jednej strony lęk, z drugiej zaś obrzydzenie w stosunku do atakowanego obozu. W dalszej konsekwencji

28 Zob. R. Dmowski Myśli nowoczesnego Polaka, Wydawnictwo "Nortom", Wrocław 2002 (I wyd. 1903), s. 41, 51.

29 S. Pieńkowski Kamień graniczny, "Myśl Narodowa” 1924 nr 52 s. 6. Inaczej jednak niż Dmowski i część nacjonalistów, Pieńkowski wierzył w skrajnie pojmowaną doktrynę walki ras, rozumiejąc ją jako konieczność obrony ras wyższych przed „pomieszaniem typów”. Obrony, która nie pozwalała na stosowanie uniwersalnych praw ludzkich, zasad sprawiedliwości i humanitaryzmu. Zob. P. Stachowiak Inspiracje rasistowskie..., s. 376. 
zaś - zachęcić do przeciwdziałania czy wręcz walki ze szkodliwą i niebezpieczną „zarazą"

Ów paranoiczny lęk przed „zażydzeniem” wzmacniał nienawiść, a ta z kolei uruchamiała znany z psychoanalizy mechanizm projekcji - tj. nasilające się przekonanie, że to Żydzi właśnie kierują się nienawiścią, dążąc do tego, by zniszczyć naród polski i polską tradycję artystyczną, a nawet wszelkie „aryjskie narody ducha pozbawić”32. „Talmudycznie ślepa mściwość”, dowodził Pieńkowski, nakazuje Żydom zabijać wszystko, co im nie schlebia. Jednym z objawów ich stosunku do innych nacji jest zaszczepianie czynników rozkładowych w kulturze, do których zaliczył krytyk choćby walkę awangardy z tradycją i tzw. stylem narodowym. W wypowiedziach Pieńkowskiego nie był to tylko spór o pryncypia artystyczne, godził bowiem w jego rozumienie sztuki jako strażniczki wartości narodowych i moralnych. Odbieranie jej tego posłannictwa było niczym „przecinanie tętnic”, „pozbawianie mowy”, „zadawanie ciosu w serce”. Do figury Żyda jako drapieżnej hieny, „krwiopijczego insekta” czy „oślizgłego gada” krytyk dodawał więc jeszcze jedną odsłonę - bezwzględnego oprawcy, który „związuje kulturę polską w pokutny wór judaszowy"33. Naród semicki opisywany był za pomocą właściwości tym razem jak najbardziej ludzkich, tyle że - najgorszego sortu. Ów enfant terrible ówczesnej krytyki szedł jeszcze dalej, gdy w paroksyzmie swego fanatycznego rasizmu odbierał Żydom wszystkie znamiona indywidualności, traktując całą nację jako „plazmę śluzowców”, „oślizgłą, chłodną i wstrętną plazmodię"34.

Na tworzony przezeń wizerunek Żydów składały się także odrażające i przykre dla otoczenia cechy fizyczne (brudni, parszywi, paskudni, śmierdzący, wynaturzeni i obrastający sadłem), które miały wywoływać

31 Zabiegi dehumanizacyjne były wykorzystywane także w atakach ad personam. O "Ajzyku” Słonimskim pisał Pieńkowski, że "w dalszym ciągu chodzi na dwóch nogach, trzecią poprawia binokle, a czwartą pisze bez przerwy". S. Pieńkowski Ciche bankructwo, "Myśl Narodowa" 1930 nr 31, s. 489 .

Pieńkowski pisał: „Niczym nie da się zmierzyć, z żadną złością nie da się porównać nienawiści żydów do wszystkich narodów świata. Cały Zakon mojżeszowy roi się od nakazów, nauk, wskazań i wersetów przygodnych, utrzymujących żydostwo w pogardzie i nienawiści względem wszystkich narodów, które ono gdziekolwiek i kiedykolwiek na drodze swojej napotka". S. Pieńkowski Praartysta "Myśl Narodowa” 1930 nr 33, s. 522. 
uzasadnioną fizjologiczną indiosynkrazję - analogiczną do tej, jaką odczuwa się wobec "gniazd szczurzych czy ławic szarańczych". Przede wszystkim jednak Pieńkowski piętnował rzekomo niechlubne cechy charakteru Żydów i niskie pobudki ich zachowań. W tworzonym przezeń obrazie narodu żydowskiego kumulowały się niemal wszystkie przywary ludzkości - nawet te wzajemnie się wykluczające. Krytyk dowolnie, w zależności od przyświecającego mu w danym momencie celu, wykorzystywał stereotypowe wyobrażenia składające się na potoczną definicję Żydów: przedstawiał ich więc jako programowo złośliwych, upadłych moralnie, chamskich, tchórzliwych, zaciekłych, sprytnych, podstępnych, kłamliwych, pustych, upartych, aroganckich, nieudolnych, fanatycznie ambitnych. Litanię tych wad i ułomności dopełniały także obraźliwe peryfrazy („ośle łby”, „urodzeni tandeciarze świata”, „łobuzy syjońskie” czy „chamy jawne”) oraz czasowniki mające na celu określać typowy dla Żydów sposób i charakter działania: oszukiwanie, „pustogadulstwo”, „łajdaczenie”, uprawianie pornografii, plugawienie i „duchowe pustoszenie wszystkiego, co napotykają na swej drodze". Podobny, deprecjonujący cel miały wyrażenia konotujące starość („cuchnący rozkład”, ,starcza bezpłodność”,,,odwieczny zastój jaskiniowy”, "beznadziejna i nieuleczalna skleroza nerwu twórczego" itp.) oraz wszelkie psychiczno-umysłowe patologie. Stosowanie z kolei tak wymyślnych peryfraz na określenie żydowskich twórców i krytyków, jak: „tępi jaskiniowcy”, „troglodyci ludzkości”, „ciężko myślący ignoranci”, , doktrynerzy ubóstwa i nieudolności" - negowało dodatkowo zakładaną w definicji awangardy postępowość, nowatorstwo, młodzieńczy zapal ${ }^{35}$. Natomiast sprowadzanie celowych malarskich uproszczeń czy geometryzacji kształtów do niedołęstwa, dyletantyzmu oraz braku rozeznania w powinnościach i funkcjach sztuki nie tylko dyskwalifikowało nielubianych artystów, podważając ich kompetencje, ale też ukazywało bezcelowość i jałowość ich działań do tego stopnia, by nie miały szansy znaleźć uznania i zrozumienia nawet wśród "dusz do cna cynizmem przeżartych".

Pieńkowski w sposób właściwy mowie nienawiści łączył wykluczające się wzajemnie obrazy. Z jednej strony ukazywał więc żydowskich twórców jako ograniczonych, odrażających fizycznie i ułomnych umysłowo, z drugiej zaś eksponował idące z ich strony zagrożenie i chęć zawładnięcia całym polem

35 Tu po raz kolejny Pieńkowski godził oczywiste sprzeczności - z jednej strony bowiem łączył awangardę z rewolucyjnym bolszewizmem, z drugiej zaś przedstawiał ją jako doktrynę niedołężną, anachroniczną, wsteczną. 
sztuki czy kultury ${ }^{36}$. Tworząc taki złożony, choć wewnętrznie sprzeczny obraz Żyda, krytyk mógł oddziaływać zarówno na umysł, zmysły, jak i uczucia odbiorcy. Samo ukazanie dzieł jako bezwartościowych, nieartystycznych, a właściwie niezasługujących na miano sztuki, mogło bowiem nie wystarczać - ze względu na cechy oraz zachowania ich twórców i pochlebców (oszustwo, kłamstwo, podjudzanie itp.) wciąż miały one szansę omamić nie dość uświadomionych widzów i czytelników. Należało więc zbudować klimat oblężonej twierdzy, klimat niesłabnącego zagrożenia i czujności. Kłamliwy i spiskujący Żyd, wprost zresztą, i to wielokrotnie, nazywany wrogiem (narodu polskiego, ale też całej ludzkości), mógł przecież czaić się wszędzie. Pieńkowski sięgał więc dodatkowo po leksykę militarną, by wykazać, że Żydzi nie są zwykłą społecznością, lecz obozem mafijnym, obcymi i wrogimi przybyszami, uzurpatorami, agentami, prowokatorami, bezczelną szajką bolszewicką czy falangą pacyfikatorów. I, jak na wrogów przystało, „plugawią”, zatruwają, działają w przebraniu, maskują się, prowadzą wojnę cywilną, szykują rewolucje, prowokują, sieją propagandę, okupują i czynią spustoszenia, uprawiają terror i metodę żandarmską. A przy tym poniżają i obrażają polską kulturę.

Pieńkowski wykorzystywał znane, bo sprawdzone już w poprzednim stuleciu, zabiegi retoryczne. Formułował swe wypowiedzi w sposób skrajnie apodyktyczny i jednoznaczny, niepodlegający kwestionowaniu, niepozostawiający miejsca na dialog. Budował dyskurs na zasadzie bezwzględnych opozycji (my - oni) i podziałów dychotomicznych, na jednej szali kładąc żydowskich twórców, odpowiedzialnych za wszelkie zło w polu sztuki, na drugiej zaś zwalnianych od wszelkiej odpowiedzialności i wolnych od wad artystów polskich. Nie wszystkich jednak. Podział na swoich i obcych nie przebiegał jedynie według linii pochodzenia. Jak wspominałam, Pieńkowski do judoformistycznego obozu zaliczał twórców awangardowych, którzy porzucali właściwości narodowego stylu i supremację koloru na rzecz „talmudycznej geometrii". Ale na jego pochwałę nie mogli zasługiwać także ci, którzy decydowali się na wspólne z Żydami wystawy, byli pupilkami publicystów związanych z instytucjami rządowymi (jak IPS czy TOSSPO) lub „zażydzonymi” „Wiadomościami Literackimi”. W kontekście wspomnianej retoryki militarnej było to tożsame z kolaborowaniem z wrogiem, z niewolniczym

36 Na podobnej zasadzie zarzucałżydowskim twórcom z jednej strony "talmudyczną geometrię", absolutyzację formy i zamknięcie się w obszarze laboratoryjnych eksperymentów, z drugiej zaś wciąganie sztuki w sferę polityki. Zob. S. Pieńkowski Polityka w sztuce, "Myśl Narodowa” 1929 nr 55, s. 398. 
poddaniem się jego władzy.Z politowaniem spoglądał Pieńkowski też na polskich krytyków. Gardził naturalnie tymi, którzy otwarcie (w jego mniemaniu) stoją po stronie żydowskiej, jak Tadeusz Boy-Żeleński czy Mieczysław Treter. Nie szczędził im szyderczych określeń, przekręcając choćby ich nazwiska (na pucyboyów i maltreterów ${ }^{37}$ ) - przez zapis minuskułami oraz dodanie złośliwych przedrostków, stawały się one inwektywami, a zapis w liczbie mnogiej pozwalał na przeniesienie sugerowanych cech na całą grupę podobnych im osób. Ale nie oszczędził Pieńkowski także tych krytyków, którzy - choć, jak można się domyślać, sprzymierzeni byli raczej z jego obozem - nie potępili sztuki współczesnej, tj. nie wzięli udziału w antyżydowskiej ofensywie. Redaktor "Myśli Narodowej” oskarżał ich o tchórzostwo, oportunizm, chowanie się za parawanem uprzejmości lub zwykłe wygodnictwo. Nie szczędził przy tym sarkazmu i obelg, dając po raz kolejny popis swojej słowotwórczej inwencji: zawsze mili krytycy piszący „arcygrzeczne wersaliki” to pod jego piórem: „dwustołkowi”, „buziawciupki”, „małdżyrączki”, ,kręcizadki”, „wiercistopki”, "łjzawooczki”, „pudrośmieszki" ${ }^{38}$. Takie osobliwe nomina agentis, powstałe przez żartobliwo-ironiczne złożenia deminutiwów, choć dodawały tekstom kolorytu, nie były jedynie stylistyczną dekoracją, spełniać miały bowiem znacznie poważniejsze, deprecjonujące krytyków, funkcje. Ale też pokazywać ich upadek moralny: milcząc o zażydzeniu kultury, krytycy stawali się nie tyle wspólnikami, co wręcz sługami Żydów. Pieńkowski oskarżał swych kolegów o chodzenie na „żydowskiej smyczy”, „pełzanie na brzuchu przed tuwimami getta”, „tańcowanie w takt syjońskich cymbałów”, usługiwanie „W podziemnej krypcie synagogi” czy wręcz zgodę na bycie „popychadłem i obłudną kukłą w purim-balu"39. W przekonaniu o ważnej, społecznej misji krytyki - jako sumienia artystów, strażnicy moralności i narodowej posługi - obciążał swych kolegów po piórze odpowiedzialnością za kryzysową, w jego mniemaniu, sytuację na polu sztuki. Siebie natomiast określił jedynym uczciwym demaskatorem zła, który miał odwagę walczyć ze zgubnym dla Polski zażydzeniem kultury i robił to mimo braku poparcia i zrozumienia u innych. Swój bezpardonowy atak na społeczeństwo żydowskie usprawiedliwił więc poczuciem moralnego obowiązku walki z wrogiem w imię dobra narodu polskiego. Aprobata dla przemocy, która ukrywała się za militarną

S. Pieńkowski Syntezy "Myśl Narodowa” 1930 nr 6, s. 94.

Tamże, s. 94 . 
i zwierzęcą metaforyką, miała jednak wymiar nie tylko czysto językowy. Był to zresztą język używany służebnie. Język, który nie tyle opisywał, co kreował rzeczywistość - pozbawioną miejsca dla obcych. Język sprowadzający daną społeczność do zawadzających obiektów i szkodliwego robactwa, które należy zbiorowo „rzucić na stos”. Pieńkowski nie kierował swych tekstów do Żydów-przeciwników (nie można im ufać, byłby to więc zabieg bezcelowy) - kierował je przeciw Żydom-wrogom, z którymi się nie rozmawia, lecz walczy. I czynił to w stronę czytelnika, który raczej podzielał jego racje, ale któremu mogło brakować odwagi do bardziej śmiałych działań lub który potrzebował zachęty do faktycznej, nie tylko słownej agresji. Zachęty niekiedy formułowanej wprost jako wezwanie do walki ogniem z tymi, którzy sami „z tego rozkładu cuchnącego" nie zginą, gdyż są „samym tym rozkładem”" ${ }^{40}$. Wyrażał też Pieńkowski nadzieję, że już niedługo, pod ostrzem złotych strzał słońca to „kłębowisko szakali” zapadnie się w ziemię - jak „pokutujący upiór złej, chorej przeszłości" ${ }^{\prime 1}$. Pewnie nie zdawał sobie wówczas sprawy z tego, jak bardzo prorocze były to słowa.

Pieńkowski pisał: „Tysiąclecia paskudztw duchowych, gromadzonych w żydostwie rozkładają się teraz i Polskę zapowietrzają. Bez masek przeciwgazowych niepodobna zbliżyć się do tego bagna trupiego. A w końcu trzeba je będzie ogniem zniszczyć, bo żyd sam z tego rozkładu cuchnącego nie zginie. Żyd jest samym tym rozkładem, w rozkładzie czuje się najlepiej, zgnilizną żyje, pleni się i tyje". S. Pieńkowski Swojski humanizm, "Myśl Narodowa” 1933 nr 6, s. 72. Taki przemocowy język właściwy był nie tylko Pieńkowskiemu. Słynął zeń choćby rzeźbiarz Stanisław Szukalski, gdy zwracał się do narodu żydowskiego: „Konstytucja Polski nie zezwala mi na użycie karabinu maszynowego. Zmuszon jestem do tego mozolnego wyrżnięcia was - słowami, wyrzuconymi z serca umiejącego tylko tak nienawidzić, jak miłować". S. Szukalski Gudłajniarz Żydowinkler, czyli obrzezanie łapy sieczkarka, w: Teksty o sztuce i wypowiedzi polemiczne oraz korespondencja z lat 1924-1938, oprac. L. Lameński, Wydawnictwo KUL, Lublin 2013, s. 168 (pierw. „Krak” $1931 \mathrm{nr} 7$ ). ko separację Żydów w gettach, ale ich całkowitą izolację w obozach koncentracyjnych. Zob. S. Pieńkowski Wogniu walki, s. 218. 


\section{Abstract}

\section{Diana Wasilewska}

PEDAGOGICAL UNIVERSITY OF CRACOW

Anti-Semitic Discourse in Stanisław Pieńkowski's Art Criticism in Myśl Narodowa (1924-37)

Wasilewska examines Stanisław Pieńkowski's art criticism published in Myśl Narodowa, a prominent press organ of the National Democracy movement in interwar Poland. Highlighting the specifics of anti-Semitic critical discourse she analyses the way in which the figure of the Jew (the Jewish artist and the Jewish critic) is constructed as an "enemy" and what strategies and rhetorical tools Pieńkowski uses to expose and discredit his opponents. Wasilewska also examines the stylistic layer of Pieńkowski's texts, his modes of persuasion and communication games as well as the ways in which he constructs a critical subject.

\section{Keywords}

anti-Semitic discourse, hate speech, Pieńkowski, art criticism, interwar period 